\title{
The influence of cell phone users' relationship intentions on expectations and perceptions of service recovery
}

\author{
L. Kruger* and P.G. Mostert \\ WorkWell: Research Unit for Economic and Management Sciences, North-West University (Potchefstroom Campus); \\ School of Business Management, Private Bag X6001, Potchefstroom, 2520, Tel: +27124205049 \\ *To whom all correspondence should be addressed \\ liezlmarie.kruger@up.ac.za
}

\begin{abstract}
With the first-time cell phone user market quickly shrinking, it is becoming increasingly important for South African cell phone network providers to retain customers by building long-term relationships with them and consistently offering quality service. Despite cell phone network providers' best intentions, service failures do occur. Not all customers want to build relationships with cell phone network providers, and therefore it is important to consider the influence of customers' relationship intentions within a service failure and recovery setting. The purpose of the study was to determine the influence of relationship intention on expectations and perceptions of two service recovery scenarios within the cell phone industry. Non-probability convenience sampling was used to collect data from 605 cell phone users residing in Gauteng. Results indicate that as respondents' relationship intentions increase, so do their expectations that their cell phone network providers should take service recovery action. It was also found that respondents with high and moderate relationship intentions perceived service recovery strategies of their cell phone network providers including an acknowledgement, apology, explanation and rectification of the problem more favourable, compared to a service recovery strategy only rectifying the problem, than those respondents with low relationship intentions.
\end{abstract}

\section{Introduction}

The South African cell phone industry is characterised by a declining available market (Van Niekerk, 2012: 101) as competition between cell phone network providers has intensified over the last few years (Independent Communications Authority of South Africa, 2012b: 3). Customer retention is thus particularly important to South African cell phone network providers, since customer retention increases service providers' long-term profitability and, ultimately, their survival (Cant \& Erdis, 2012: 938).

Service providers therefore attempt to build long-term relationships with customers through relationship marketing strategies in an effort to retain customers (Coulter \& Ligas, 2004: 489). However, not all customers want long-term relationships with service providers (Hess, Story \& Danes, 2011: 22). Service providers should thus identify those customers with relationship intentions, as these customers want to build long-term relationships with them and would therefore be more inclined to be retained (Kumar, Bohling \& Ladda, 2003: 669).

Retaining customers is particularly challenging within a service environment as service failures, which adversely affect customer retention (Robinson, Neeley \& Williamson, 2011: 90), are inescapable due to the nature of service offerings (Harrison-Walker, 2012: 115; Tax \& Brown, 1998: 87; Tsarenko \& Tojib, 2011: 383). South African cell phone network providers are, as with all other service providers, inclined to experience service failures (Independent
Communications Authority of South Africa, 2012a: 28) which could lead to customers switching to other cell phone network providers (South African Audience Research Foundation, 2012) should they be dissatisfied with service provisioning or when experiencing a service failure.

As a result, service providers use service recovery strategies as contingency measures to retain customers after service failures. Service recovery strategies are thus essential in maintaining customer loyalty and retention (Huang, 2011: 513; Robinson et al., 2011: 96). Customers react differently to service failure and service recovery (Bunker \& Ball, 2008: 43). Consequently, service recovery will only achieve its purpose if customers' expectations of service recovery are met (Bhandari, Tsarenko \& Polonsky, 2007: 181). Longterm relationships between service providers and customers have been found to both exacerbate (Kim, Ok \& Canter, 2012: 74) and reduce (Hess, Ganesan \& Klein, 2003: 140) customers' expectations of service recovery. These inconclusive findings and the gap in literature on the influence of relationship intention on expectations and perceptions of service recovery are addressed in this article. The purpose of this article is therefore to determine the influence of cell phone users' relationship intentions on expectations and perceptions of service recovery. The results will not only provide practical guidelines for cell phone network providers' service recovery efforts when service failures occur, but will also build theory with regard to the influence of relationship intention on expectations and perceptions of service recovery. 


\section{Literature review}

\section{Service failure}

Service failures are unavoidable (Harrison-Walker, 2012: 115) due to the inseparable, intangible, perishable and heterogeneous nature of services (Berry, 2002: 74; Grönroos, 2004: 100). For this reason, customers have expectations about which service failures are likely to occur and which failures should not occur if employees perform their functions properly (Bell \& Ridge, 1992: 61; Michel, 2004: 369). Expectations thus form part of customers' zones of tolerance for service delivery. The zone of tolerance is considered to be the gap between customers' expectations about the level of service they want to receive, and customers' expectations about the level of service they are willing to accept (Zeithaml, Berry \& Parasuraman, 1993: 6). Service failures thus occur whenever a service does not meet customers' expectations of service delivery, and service delivery falls outside the customer's zone of tolerance, irrespective of whether the customer or service provider was at fault (Bateson \& Hoffiman, 2011: 352).

If the service failure was simply the result of an accident, customers may experience annoyance or irritation, whereas a service failure resulting from incompetence may induce frustration, while a deliberate and avoidable service failure could evoke anger from customers (Harrison-Walker, 2012: 120). Customer dissatisfaction caused by service failures therefore has the possibility to lead to negative publicity, negative word-of-mouth, lingering anger, resentment, hostility, exit intentions, and customer switching behaviour (Nikbin, Ismail, Marimuthu \& Abu-Jarad, 2011: 19; Tsarenko \& Tojib, 2011: 382; Yuksel, Kilinc \& Yuksel, 2006: 11). The problem that service providers face as a result of service failure thus involves the negative impact of service failures on customer retention and service providers' long-term profitability (Robinson et al., 2011: 90). For this reason, service providers should make use of service recovery strategies to maintain customer relationships (Tax \& Brown, 1998: 87).

\section{Service recovery}

Service recovery is regarded as service providers' reactions to, and handling of, service failures to restore customer satisfaction (Lovelock \& Wirtz, 2011: 376). Service providers can follow a number of service recovery strategies which could either be tangible or intangible in nature. With regard to more tangible service recovery strategies, service providers can follow one of three options. Firstly, compensatory service recovery strategies can be used to offset the costs of the service failure by compensating customers (Bateson \& Hoffman, 2011: 368-369). Secondly, restoration strategies entail offering an identical offering, corrections to the original offering, or offering a substitute to customers (Bateson \& Hoffman, 2011: 368-369). Lastly, reimbursement strategies in the form of a refund or store credit can also be employed (Bateson \& Hoffman, 2011: 368-369).
However, since it is an essential human need to understand why things went wrong, tangible compensation might not always be an effective service recovery strategy (Wang \& Mattila, 2011: 435). Therefore, service providers can also opt for intangible recovery strategies, including using apologetic strategies where front-line staff or management apologise to customers (Bateson \& Hoffman, 2011: 368369). An apology can also aid customers' perceived fairness of service recovery (Lin, Wang \& Chang, 2011: 511; Tax \& Brown, 1998: 80; Tax, Brown \& Chandrashekaran, 1998: 72). When customers experience value added service failures (such as billing errors), an apology or proactive response could be the best option to restore satisfaction (Smith, Bolton \& Wagner, 1999: 369) as an apology aids in forgiveness (McCullough, Worthington \& Rachal, 1997: 327). An apology or proactive response with no compensation was found to increase customers' satisfaction after service failure, making additional monetary compensation unnecessary (Blodgett, Hill \& Tax, 1997: 202; Dunning, Pecotich \& O'Cass, 2004: 568; Smith et al., 1999: 369). Yi and Lee (2005: 12) accordingly advocate that in certain situations a simple apology will suffice. Furthermore, the importance of explanations should not be underestimated, as customers can be satisfied and remain loyal if they received adequate and truthful information about a service failure without receiving tangible compensation (Wang \& Mattila, 2011: 434).

From the discussion it becomes apparent that service providers may not have to offer customers full refunds or exchanges to achieve satisfaction through service recovery (Blodgett et al., 1997: 202). Service providers could choose to combine different service recovery strategies as opposed to selecting a single response option. Smith et al. (1999: 369) concur by suggesting that service recovery should rather be viewed as a bundle of strategies that service providers can use in different combinations to restore customer satisfaction.

Since customers respond differently to service recovery strategies (Seawright, DeTienne, Bernhisel \& Larson, 2008: 254, 267), all customers do not merit the same level of service recovery by service providers. It is customers" expectations of both the recovery process as well as the outcome thereof (Andreassen, 2000: 166) that will influence their perceptions of service recovery strategies (Bhandari et al., 2007: 181). Bhandari et al. (2007: 181) explain that customers' expectations of service recovery can be based on past experience with the service provider or even service recovery experiences with service providers offering completely different products and services.

Huang and Chang (2008: 1229) opine that certain customers have higher expectations for service recovery than others. Kim et al. (2012: 74) support this view by explaining that customers with already established relationships with service providers have higher expectations for service recovery, based on their cumulative satisfaction with past experiences with these service providers, than customers without a relationship. However, on the other hand, Hess et al. (2003: 140) argue that customers who expect the 
relationship to continue have lower expectations of service recovery resulting in increased satisfaction after service recovery. It is therefore important to determine the influence of customer relationships on expectations and perceptions of service recoveries.

\section{Relationship marketing and relationship intention}

Service providers and customers become mutually dependent on each other in long-term relationships due to the benefits each party receives from these relationships (Price \& Arnould, 1999: 51). Service providers enjoy increased sales, market share and profits (Jena, Guin \& Dash, 2011: 23), while customers benefit from security in terms of a feeling of control and a sense of trust in the service provider, as well as minimised purchasing risks and reduced costs during decision-making between services (Grönroos, 2004: 99). Customers perceive these benefits after repetitive satisfactory interactions with the service provider (Dorai \& Varshney, 2012: 407), as they become familiar with the service provider with whom they have a long-term relationship (Grönroos, 2004: 99).

Although long-term relationships could result in increased customer loyalty and retention (Coulter \& Ligas, 2004: 490 ), only certain customers want to build relationships with service providers, while others prefer transactional contact (Beetles \& Harris, 2010: 353-354; Hess et al., 2011: 22; Palmatier, Scheer, Evans \& Arnold, 2008: 179-180; Petruzzellis, 2010: 625). For this reason, service providers should consider customers' relational intentions (Dalziel, Harris \& Laing, 2011: 399, 420) before any relationship building strategies are attempted. Kumar et al. $(2003 ; 669)$ advocate that customers with relationship intentions (customers with a high affinity towards and trust in the service provider, with the intention to build a relationship with the particular service provider), should be targeted with relationship strategies. Kumar et al. (2003: 670) proposed five constructs that should be used to determine customers' relationship intentions, namely involvement, expectations, fear of relationship loss, feedback and forgiveness.

\section{Involvement}

Customers with higher relationship intentions engage in relationship building activities with their service providers as they want to be involved with their service providers (Kumar et al., 2003: 670). Highly involved customers desire to be part of, and involved with, the solutions to any problems (or service failures) which may occur during the interaction between the service provider and customer, and are more concerned about fair treatment during service recovery, than uninvolved customers (Varki \& Wong, 2003; 89).

\section{Expectations}

Service failures occur when customers' expectations pertaining to the core service, and any other service breakdowns related to value added services (such as billing errors by service providers), are not met (Komunda \& Osarenkhoe, 2012: 83). Furthermore, should a service failure occur, customers develop expectations for service recovery (Bhandari et al., 2007: 181). Kumar et al. (2003: 670) are of the opinion that customers with higher relationship intentions develop higher expectations of and concern with regard to the products and services of their service providers.

\section{Fear of relationship loss}

Customers with higher relationship intentions will fear the consequences of losing their bonds and relationships with their service providers (Kumar et al., 2003: 670), which, in turn, might cause these customers to feel betrayed by service failures, resulting in lower tolerance for service failures (Mattila, 2004: 144). For this reason, a service recovery strategy combining an apology with a tangible compensation, may not be enough to restore relationships after service failures experienced by customers with strong bonds with their service providers (Mattila, 2004: 144).

\section{Feedback}

Customers who provide feedback after service failures act construetively within the relationship to repair it after service failures (Hedrick, Beverland \& Minahan, 2007: 70), as feedback enables service providers to deploy service recovery strategies. Without customer feedback, service providers may not have the opportunity to rectify service failures, salvage the relationship through effective service recovery strategies, and prevent the same service failure from occurring again (Lin et al,, 2011: 529-530). Kumar et al. (2003: 670) accordingly propose that customers with higher relationship intentions will communicate their expectations by providing feedback (both positive and negative) to service providers.

\section{Forgiveness}

Kumar et al. (2003: 670) also theorised that customers with higher relationship intentions will give service providers another chance if their expectations are sometimes not fulfilled, as the relationship with service providers is valued more than unsatisfied expectations. Forgiveness is not only a function of individual traits, but also of environmental variables such as procedural justice perceptions (Aquino, Tripp \& Bies, 2006: 666). Customers with close relationships with their service providers might see no need to use valuable cognitive resources to go through extensive attribution processes in response to a service failure, but would rather forgive the service provider automatically (Karremans \& Aarts, 2007: 916). Furthermore, customers' emotional reactions influence forgiveness more than cognitive judgements when customers consider attribution of service failures (Takaku, 2001: 503). Also, service recovery strategies in line with customers' expectations of service recovery, may accelerate the forgiveness process (Tsarenko \& Tojib, 2011; 388). 
Based on the literature review it can be concluded that customers' relationship intentions (in terms of the underlying constructs, namely involvement, expectations, fear of relationship loss, feedback and forgiveness), along with their expectations of service recovery, should influence customers' perceptions of service recovery.

\section{Problem statement}

Regardless of service providers' best efforts to continuously meet customers' service delivery expectations, service failures do occur (Harrison-Walker, 2012: 115; Tsarenko \& Tojib, 2011: 383, 391). South African cell phone network providers, despite preconceived intentions to prove otherwise, do experience service failures (Independent Communications Authority of South Africa, 2012a: 28). As alternative cell phone network providers are available (South African Audience Research Foundation, 2012) and because the first-time cell phone user market is quickly shrinking (Van Niekerk, 2012: 101), retaining existing customers is becoming increasingly important within the South African cell phone industry. Since service failures negatively impact customer retention and therefore service providers' profitability (Robinson et al., 2011: 90), service failures are not only frustrating to customers, but also problematic to service providers. Consequently, the challenge facing service providers lies in negating the negative effects of service failures through service recovery (Tax \& Brown, 1998: 87) in an attempt to restore customer satisfaction and retain customers.

Service recovery strategies are, however, only successful if customers' expectations of service recovery are met (Bhandari et al., 2007: 181). Previous research is not conclusive on whether relationships between service providers and customers increase customers' expectations of service recovery (Kim et al., 2012: 74-75, Ma, 2012: 26; Tax et al., 1998: 72), or lower customers' expectations of service recovery (Hess et al., 2003: 140). Although service providers can use relationship marketing to build long-term relationships with customers (Coulter \& Ligas, 2004: 489), only certain customers have relationship intentions (Kumar et al., 2003: 667) and want to establish long-term relationships with their service providers (Hess et al., 2011: 22). Within the cell phone industry, Kruger and Mostert (2013: 356-366) argue for the reconsideration of the assumption that contractual agreements indicate the existence of relationships between cell phone network providers and their customers, as customers' relationship intentions had no relationship with the presence or absence of contractual agreements. Furthermore, Seo, Ranganathan and Brady (2008: 194) agree that contractual agreements between cell phone network providers and customers bound customers only for the duration of the contracts and will not result in customer retention. Therefore, contractual agreements (or the pay-as-you-go option) between cell phone network providers and customers do not indicate the existence of fixed relationships (or the absence thereof) between these two parties. For this reason, both contractual and pay-as-you-go cell phone customers can have relationship intentions towards their cell phone network providers.

By considering pursuing long-term relationships with customers in an effort to retain them, cell phone network providers can benefit from a better understanding of cell phone users' relationship intentions, specifically within a service failure and service recovery setting. The purpose of this study is thus to determine the influence of cell phone users' relationship intentions on their expectations and perceptions of service recovery. For this purpose, the following objectives have been formulated for this article:

- Determine cell phone users' expectations of cell phone network providers' service recovery strategies;

- Determine the relationship between relationship intention and cell phone users' expectations of cell phone network providers' service recovery strategies;

- Determine cell phone users' perceptions of cell phone network providers' service recovery strategies;

- Determine the relationship between relationship intention and cell phone users' perceptions of cell phone network providers' service recovery strategies; and

- Compare the relationships between cell phone users' relationship intention levels and perceived service recovery for two different service recovery scenarios.

\section{Methodology}

Research design, sampling procedure, study population and data collection

Descriptive research aided this study. Quantitative research in the form of non-probability convenience sampling was used for this study as no sampling frame could be obtained from any cell phone network provider. The study population comprised Gauteng residents, 18 years or older, who have used a cell phone network provider for three years or longer. Marketing Management students were trained as fieldworkers and supervised by the researchers concerned. The fieldworkers approached prospective respondents in their immediate residential suburbs in and around Johannesburg based on convenience and assigned quotas (relating to gender and population group) to obtain a demographically diverse sample. Fieldworkers firstly determined whether prospective respondents qualified to take part in the study (by being part of the study population) and if that was the case secondly, asked prospective respondents to take part in the study. When prospective respondents agreed to take part in the study fieldworkers conducted personal in-home interviews in the respondent's home using interviewer-administered questionnaires. Interviewer-administered questionnaires were appropriate as the questionnaire for this study contained a service failure scenario and two service recovery scenarios that had to be explained to respondents (Bradley, 2007: 128). 


\section{Questionnaire design}

The questionnaire used in the study comprised of four sections, each dealing with specific aspects of the study. Where scale items were used, a 5-point unlabelled Likert scale was used. Unless otherwise specified, the scale used throughout the questionnaire was anchored by $1=$ strongly disagree, and $5=$ strongly agree.

The objective of Section A was to capture classification and patronage habit information concerning respondents' cell phone network providers. Section B measured relationship intention by means of the measurement scale as proposed by Kruger and Mostert (2012: 45), as it has demonstrated to be valid and reliable to measure relationship intention within a South African context. The scale for the relationship intention measurement scale was anchored by $1=$ no, definitely not, and 5 = yes, definitely.

In Section C respondents were presented with a service failure scenario within the cell phone industry. Instead of asking respondents to recall an event which can result in biases due to memory lapse, a service failure scenario is recurrently used in service failure research (Kim \& Ulgado, 2012: 161; Long-Tolbert \& Gammoh, 2012: 399; Prasongsukarn \& Patterson, 2012: 513). The service failure scenario reads as follows: After signing a contract with your cell phone network provider for 150 free minutes to any cell phone number during office hours, you receive your bill and see that you have in fact been charged for all the calls you made during office hours and not just for the calls exceeding the 150 minute frame. After respondents had been presented with the service failure scenario, respondents' expectations of service recovery were measured with items adapted from Andreassen (2000: 172) and McCollough, Berry and Yadav $(2000 ; 127)$.

Respondents were subsequently presented with two service recovery scenarios for the service failure scenario. After each scenario respondents rated statements regarding their perception of service recovery (items adapted from Casado, Nicolau \& Mas, 2011: 48; Holloway, Wang \& Beatty, 2009: 390; Huang, 2011: 514; Lin et al., 2011: 522-523; McCollough et al., 2000: 127) based on how they would feel if they had received the service recovery described in the scenarios. The first service recovery scenario used (from here on referred to as service recovery scenario 1) asked respondents how they would feel if the cell phone network provider rectified the problem so that it would not occur in future, but did nothing more in response to the above described scenario. The second service recovery scenario used (from here on referred to as service recovery scenario 2), asked respondents how they would feel if, in addition to rectifying the problem so that it would not occur in future, the cell phone network provider acknowledged the problem, apologised and explained why the problem had occurred. Finally, Section D obtained demographic details including population group, gender, and monthly cell phone expenses. Before fielding the final questionnaire used in the study, it was pre-tested with 27 respondents from the study population with the purpose of identifying and correcting any possible problems respondents may experience with the questionnaire. During the pre-test respondents did not indicate distress while completing the questionnaire and preliminary analyses did not result in item reduction.

\section{Data analysis}

Statistical processing was done using the Statistical Package for Social Sciences (SPSS Version 21) and the SAS statistical programme (SAS Version 9,3). Data was captured using SPSS, keypunching errors were rectified, and poor quality questionnaires with more than 20 missing values were discarded which resulted in a total of 605 usable questionnaires being obtained. The study used a significance level of 0,05 (thus a confidence level of $95 \%$ ). However, the strength of the significance should also be considered (Cohen, 1988: 25-26). Therefore, Cohen's r-values for Pearson product-moment correlation coefficients (rounded off to 1 decimal), considered as small at 0,1 , medium at 0,3 and large at 0,5 (Cohen, 1988: 79-81), were determined. Furthermore, Partial Eta Squared values $\left(\eta^{2}\right)$ for the mixed between-within subjects analysis of variance (also referred to as a split-plot Anova or Spanova), considered as small at 0,01 , medium at 0,06 and large at 0,14 (Cohen, 1988; 284287 ), were also determined and rounded off to 2 decimals. Both medium and large effect sizes were regarded as practically significant when results were interpreted as Cohen (1988: 20) maintains that medium effect sizes have ample practical effect (i.e. differences between respondent groups can be noticed with the naked eye).

\section{Results}

\section{Respondent profile and patronage habits}

Table 1 presents a profile and patronage habits of respondents participating in the study. 
Table 1: Respondent profile and patronage habits

\begin{tabular}{|c|c|c|}
\hline Variable & Response categories & $\%$ \\
\hline \multirow[t]{4}{*}{ Population group } & Asian / Indian & 21,2 \\
\hline & Black African & 33,5 \\
\hline & Coloured & 17,0 \\
\hline & White & 28,3 \\
\hline \multirow[t]{2}{*}{ Gender } & Male & 46,3 \\
\hline & Female & 53,7 \\
\hline \multirow[t]{5}{*}{ Current cell phone network provider } & 8 -ta & 3,3 \\
\hline & Cell C & 16,5 \\
\hline & MTN & 34,4 \\
\hline & Virgin Mobile & 2,8 \\
\hline & Vodacom & 43,0 \\
\hline \multirow[t]{2}{*}{ Contract or pay-as-you-go-customer } & Contract & 52,2 \\
\hline & Pay-as-you-go & 47,8 \\
\hline \multirow{6}{*}{$\begin{array}{l}\text { Reason best describing why current cell phone network } \\
\text { provider is used }\end{array}$} & The package is cheap and affordable & 32,4 \\
\hline & The total package suits the customer's needs & 35,0 \\
\hline & Easy billing & 6,3 \\
\hline & Handsets offered & 4,5 \\
\hline & The cell phone network provider has coverage everywhere & 17,7 \\
\hline & Other reason & 4,1 \\
\hline \multirow[t]{5}{*}{ Monthly cell phone expenses } & $\leq \mathrm{R} 100$ & 15,9 \\
\hline & R101 to R250 & 36,2 \\
\hline & $\mathrm{R} 251$ to $\mathrm{R} 400$ & 26,6 \\
\hline & $\mathrm{R} 401$ to $\mathrm{R} 600$ & 11,2 \\
\hline & $>\mathrm{R} 600$ & 10,1 \\
\hline
\end{tabular}

From Table 1 it is evident that $33,5 \%$ of the respondents were Black Africans, 28,3\% were Whites, $21,1 \%$ were Asians/Indians and 17\% were Coloureds. Furthermore, $53,7 \%$ of the respondents were female and $46,3 \%$ were male. The majority of respondents used Vodacom $(43 \%)$ or MTN $(34,4 \%)$ as their cell phone network provider. Just over half of the respondents had a contract with their cell phone network provider $(52,2 \%)$, while $47,8 \%$ of the respondents were pay-as-you-go customers. The majority of respondents used their current cell phone network provider as the total package suits their needs ( $35 \%$ ), followed by the package being cheap and affordable $(32,4 \%)$, and reasoning that the cell phone network provider has coverage everywhere $(17,7 \%)$. Furthermore, the majority of respondents had spent between R101 to R250 (36,2\%) or R251 to R400 (26,6\%) on monthly cell phone expenses.

\section{Reliability and validity}

To determine the internal consistency reliability of the measurement scales used in this study, Cronbach's alpha coefficient values were calculated. Table 2 presents the Cronbach's alpha coefficient values for the constructs of this study where a value of 0,7 and higher is considered to indicate reliability (Pallant, 2010: 6). To determine the underlying dimensions and construct validity of the measures used in this study, exploratory factor analyses were performed. The measures of sampling adequacy (MSA) were above 0,85 , and more than $55 \%$ of the variance was explained by the underlying dimensions of each measurement scale used in this study. By examining the eigenvalue for each measurement scale, the underlying dimensions were uncovered and labelled. The underlying dimensions uncovered during the exploratory factor analyses and mean scores for the underlying dimensions, are also presented in Table 2. 
Table 2: Cronbach's alpha coefficient values, underlying dimensions of the measurement scales and mean scores

\begin{tabular}{|c|c|c|c|}
\hline \multicolumn{2}{|c|}{ Constructs } & Cronbach's alpha value & Mean \\
\hline \multicolumn{2}{|c|}{ Relationship intention (26 items) } & 0,90 & 3,60 \\
\hline \multirow{5}{*}{$\begin{array}{l}\text { Underlying dimensions of } \\
\text { relationsbip intention }\end{array}$} & Involvement ( 5 items) & 0,83 & 3,84 \\
\hline & Expectations (6 items) & 0,73 & 4,43 \\
\hline & Fear of relationship loss (5 items) & 0,86 & 3,00 \\
\hline & Feedback ( 5 items) & 0,80 & 3,66 \\
\hline & Forgiveness (5 items) & 0,82 & 2,92 \\
\hline \multicolumn{2}{|c|}{ Expectations of service recovery ( 9 items) } & 0,83 & 4,45 \\
\hline \multirow{2}{*}{$\begin{array}{l}\text { Underlying dimensions of } \\
\text { expectations of service recovery }\end{array}$} & No action by service provider* ( 1 item) & No value for 1 item & 1,50 \\
\hline & Action by service provider ( 8 items) & 0,85 & 4,45 \\
\hline \multicolumn{2}{|c|}{ Perceived service recovery scenario 1 ( 7 items) } & 0,96 & 2,90 \\
\hline \multicolumn{2}{|c|}{ Perceived service recovery scenario 2 ( 7 items) } & 0,94 & 4,24 \\
\hline
\end{tabular}

* Item was reverse scored

From Table 2 it can be deduced that the measurement scales were reliable and valid to measure the relationship intentions, expectations of service recovery and perceived service recovery after both service recovery scenario 1 and service recovery scenario 2 of cell phone users residing in Gauteng.

\section{Levels of relationship intention}

From Table 2 it can also be seen that respondents participating in this study had a tendency towards higher relationship intentions towards their cell phone network providers (mean $=3,60$ ). In order to determine the influence of the relationship intention level on perceived service recovery, respondents were grouped according to their levels of relationship intention by using the 33,3 and 66,6 percentiles as cut-off points on their overall mean scores for relationship intention. The cut-off points of means for categorising the groups were 3,34615 and 3,88462 . From this analysis, 200 respondents were categorised as having low relationship intentions (mean $=2,90), 208$ respondents were categorised as having moderate relationship intentions (mean $=3,62$ ), and 197 respondents were categorised as having high relationship intentions (mean=4,29).

\section{Relationship intention and service recovery expectations}

As indicated in Table 2, respondents' expectations of service recovery had two underlying dimensions, labelled as no action by the service provider, and action by the service provider. Reverse scoring was used for expecting no action by the service provider, which entails that a low score indicates respondents expect their cell phone network providers to take action, and a high score indicates that respondents would not expect their cell phone network providers to take action. The mean score for no action by the service provider in response to the service failure scenario was 1,50 , indicating that respondents have high expectations that their cell phone network providers will apply service recovery strategies after a billing error as described in the service failure scenario. This finding is supported by the mean score obtained for action by the service provider, namely 4,45 , indicating that respondents hold high expectations that their cell phone network providers should take service recovery action. It can therefore be concluded that respondents participating in this study held high expectations that their cell phone network providers should use service recovery strategies after a billing error as described in the service failure scenario.

The relationship between respondents relationship intentions and expectations of service recovery were investigated using Pearson product-moment correlation coefficients. Table 3 presents the r-value of the Pearson product-moment correlation coefficients between respondents' relationship intentions with expecting no action, as well as expecting action by the cell phone network provider.

\section{Table 3: Relationship intention and expectations of service recovery}

\begin{tabular}{l|c}
\hline Correlation between relationship intention with: & r-value \\
\hline $\begin{array}{l}\text { Expect no action by the cell phone network } \\
\text { provider }\end{array}$ & $-0,1$ \\
\hline Expect action by the cell phone network provider & $0,3^{*}$ \\
\hline *Correlation significant at the 0,05 level
\end{tabular}

From Table 3 it can be deduced that there was not a statistical significant correlation between respondents" relationship intentions with expecting no action by the cell phone network provider. Table 3 does however indicate a statistically significant positive correlation between respondents' relationship intentions and expecting action by cell phone network providers, where expecting action from cell phone network providers increases as respondents' relationship intentions increase. The correlation effect between respondents' relationship intentions and expecting action by the cell phone network provider was medium $(r=0,3)$. It can therefore be concluded that the higher respondents' relationship intentions, the higher the expectation that cell phone network providers should take action after a billing error as described in the service failure scenario. 
As each item in the underlying dimension of expectations of service recovery (labelled as action) measured a different service recovery strategy, the relationship between respondents' relationship intentions and expectations of service recovery for each action item was also investigated using Pearson product-moment correlation coefficients. Table 4 presents the mean and r-value of the Pearson product-moment correlation coefficients between respondents' relationship intentions with each item. Cell phone network provider is abbreviated as CNP in Table 4.

Table 4: Relationship intention and action expectations of service recovery

\begin{tabular}{|c|c|c|}
\hline $\begin{array}{c}\text { Correlation between relationship } \\
\text { intention with: }\end{array}$ & Mean & $\mathrm{r}$-value \\
\hline $\begin{array}{l}\text { The CNP should give an explanation for } \\
\text { what happened }\end{array}$ & 4,60 & $0,2 *$ \\
\hline $\begin{array}{l}\text { The CNP should apologise to me for what } \\
\text { happened }\end{array}$ & 4,62 & $0,2 *$ \\
\hline $\begin{array}{l}\text { The CNP should apologise to me in writing } \\
\text { for the poor service I received }\end{array}$ & 3,93 & $0,2 *$ \\
\hline $\begin{array}{l}\text { The CNP should acknowledge that the } \\
\text { problem did occur }\end{array}$ & 4,67 & $0,2^{*}$ \\
\hline $\begin{array}{l}\text { The CNP should show understanding for my } \\
\text { situation }\end{array}$ & 4,62 & $0,2^{*}$ \\
\hline $\begin{array}{l}\text { The CNP should take responsibility for the } \\
\text { problem and solve it }\end{array}$ & 4,74 & $0,2^{*}$ \\
\hline A manager should intervene in the situation & 4,10 & $0,3 *$ \\
\hline I should receive compensation from the CNP & 4,29 & $0,1^{*}$ \\
\hline
\end{tabular}

From Table 4 it can be observed that all items achieved mean scores above the midpoint of the 5-point Likert scale used. In fact, with the exception of the item stating The cell phone network provider should apologise to me in writing for the poor service I received (mean=3,93), all items had mean scores above 4,10 . It is therefore concluded that respondents hold high expectations that their cell phone network providers should take responsibility for a billing error and solve it, show understanding, apologise and explain why the billing error occurred.

Table 4 also indicates that statistically significant positive correlations exist between relationship intention and all the items measuring action expectations of service recovery where expecting an explanation, apology (both in person and in writing), acknowledgement that the problem occurred, showing of understanding, taking of responsibility, the intervention of a manager, and receiving compensation from the cell phone network provider increase as relationship intention increases. However, all the correlation effects were small (and therefore not of practical significance), except for the medium correlation between respondents' relationship intentions and $A$ manager should intervene in the situation $(\mathrm{r}=0,3)$. It can therefore be concluded that the higher respondents' relationship intentions, the higher their expectations that a manager should intervene when their cell phone network providers make a billing error.
Relationship intention and perceived service recovery after service recovery scenarios 1 and 2

From Table 2 it is construed that the mean score for perceived service recovery scenario 1 is 2,90 , which is below the midpoint of the scale $(3,00)$. Respondents thus considered service recovery scenario 1 , where the billing error was only rectified as insufficient. It could also be seen from Table 2 that the mean score for perceived service recovery after service recovery scenario 2 is 4,24 , indicating that respondents considered service recovery scenario 2 , where an acknowledgement, apology, explanation and rectification of the problem formed the service recovery strategy, as favourable. The relationship between respondents' relationship intentions and perceived service recovery after service recovery scenarios 1 and 2 was investigated using a Pearson product-moment correlation coefficient. Table 5 presents the r-values of the Pearson product-moment correlation coefficients between respondents' relationship intentions with perceived service recovery after service recovery scenarios 1 and 2 .

Table 5: Relationship intention and perceived service recovery after service recovery scenarios 1 and 2

\begin{tabular}{l|c}
\hline Correlation between relationship intention with: & r-value \\
\hline $\begin{array}{l}\text { Perceived service recovery after service recovery } \\
\text { scenario 1 }\end{array}$ & $0,2^{*}$ \\
\hline $\begin{array}{l}\text { Perceived service recovery after service recovery } \\
\text { scenario 2 }\end{array}$ & $0,3^{*}$ \\
\hline${ }^{*}$ Correlation significant at the 0,05 level
\end{tabular}

From Table 5 it is evident that a statistical significant positive correlation between respondents' relationship intentions and perceived service recovery after service recovery scenario 1 exists, where favourable perceptions of perceived service recovery increases as relationship intention increases. However, the strength of the correlation is small $(\mathbf{r}=0,2)$ and therefore not of practical significance. It can therefore be concluded that although there is a statistical significant relationship between respondents' relationship intentions and perceived service recovery where only rectification of the billing error occurred, this relationship is not of practical significance.

It can also be seen from Table 5 that a statistically significant positive correlation $(\mathrm{r}=0,3)$ between respondents' relationship intentions and perceived service recovery after service recovery scenario 2 exists, where favourable perceptions of perceived service recovery increase as relationship intention increases. The correlation effect between respondents' relationship intentions and service recovery after service recovery scenario 2 was medium $(r=0,3)$. It can therefore be concluded that the higher respondents' relationship intentions, the higher their favourable perceptions of perceived service recovery including an acknowledgement, apology, explanation and rectification of the problem by their cell phone network providers after a billing error, will be. 
Relationship intention and the difference between perceived service recovery after service recovery scenarios 1 and 2

A mixed between-within subjects analysis of variance (also referred to as a split-plot Anova) was performed to assess the impact of respondents' relationship intention levels on perceived service recovery for the two service recovery scenarios. The skewness and kurtoses for all groups were below 2,0 and 7,0 respectively, and normality is therefore not considered to be violated (Curran, West \& Finch, 1996: 26). Conversely, Levene's test of equality was significant for one of the scenarios (where $\mathrm{p}<0,001$ for perceived service recovery scenario 1 and $p=0,296$ for perceived service recovery scenario 2) thus violating the assumption of homogeneity of variance. Furthermore, Box's M test of equality of covariance was also significant (where $\mathrm{p}<0,001$ ), violating the assumption of covariance. However, Stevens (2009: 434) argues that the analysis of variance is reasonably robust to violations of the assumption of homogeneity of variance if the group sizes are reasonably similar as is the case in this study.

It is important to note that the interaction effect was statistically significant. For this reason, the plot also guided the interpretation of the analysis. Table 6 presents the descriptive statistics for each relationship intention level for perceived service recovery after service recovery scenario 1 and perceived service recovery after service recovery scenario 2, as well as the main effects and between subjects effect in terms of the Wilk's Lambda (statistical significance at the 0,05 level) and Partial Eta Squared values (effect sizes).

Table 6: Relationship intention and differences between perceived service recovery after service recovery scenarios 1 and 2

\begin{tabular}{|c|c|c|c|c|c|c|c|c|c|c|}
\hline \multirow{2}{*}{$\begin{array}{l}\text { Relationship } \\
\text { intention levels }\end{array}$} & \multicolumn{3}{|c|}{$\begin{array}{l}\text { Perceived service recovery } \\
\text { scenario } 1\end{array}$} & \multicolumn{3}{|c|}{$\begin{array}{l}\text { Perceived service recovery } \\
\text { scenario } 2\end{array}$} & \multicolumn{2}{|c|}{ Main effects } & \multicolumn{2}{|c|}{$\begin{array}{c}\text { Between subjects } \\
\text { effect }\end{array}$} \\
\hline & Mean & SD & n & Mean & SD & $n$ & $p$-value & $\eta^{2}$ & $p$-value & $\eta^{2}$ \\
\hline Low & 2,77 & 0,91 & 200 & 3,93 & 0,76 & 200 & \multirow{3}{*}{$0,000^{*}$} & \multirow{3}{*}{0,60} & \multirow{3}{*}{$0,000^{*}$} & \multirow{3}{*}{0,06} \\
\hline Moderate & 2,85 & 1,01 & 208 & 4,30 & 0,68 & 208 & & & & \\
\hline High & 3,07 & 1,33 & 197 & 4,51 & 0,72 & 197 & & & & \\
\hline
\end{tabular}

*Wilk's Lambda significant at the 0,05 level

From Table 6 it can be deduced that there was a significant large main effect $\left(\eta^{2}=0,60\right)$ for perceived service recovery where the favourable perceptions of service recovery increased from service recovery scenario 1 to service recovery scenario 2 . The between subjects effect comparing the different levels of relationship intention was also significant with a medium effect size $\left(\eta^{2}=0,06\right)$ suggesting that the higher relationship intention levels, the more favourable perceptions of service recovery were. Mean scores indicate that respondents with high (mean=4,51) and moderate (mean $=4,30$ ) relationship intentions perceive service recovery scenario 2 more favourable, compared to service recovery scenario 1 (mean $=3,07$ and mean $=2,85$ respectively), than respondents with low relationship intentions (mean $=3,93$ for service recovery scenario 2 and mean $=2,77$ for service recovery scenario 1 ). It can therefore be concluded that respondents with high and moderate relationship intentions perceived the service recovery strategies of their cell phone network providers including an acknowledgement, apology, explanation and rectification of the problem (service recovery scenario 2) more favourable, compared to a service recovery strategy only rectifying the problem (service recovery scenario 1 ), than respondents with low relationship intentions.

\section{Discussion and recommendations}

Cell phone network providers need to retain customers in the competitive cell phone industry (Morrisson \& Huppertz, 2010: 250), but service failures complicate this undertaking as service failures negatively impact customer retention (Robinson et al., 2011, 90). Although building relationships with customers could support customer retention (Coulter \& Ligas, 2004: 498), only certain customers have relationship intentions towards, and want to build relationships with, their cell phone network providers (Kumar et al., 2003: 669). This article determined the influence of cell phone users' relationship intentions on expectations of service recovery, as well as two perceived service recovery scenarios following a service failure scenario.

Results indicated that all measurement scales used in this article were reliable and valid under cell phone users living in Gauteng. Considering the influence of relationship intention, results indicated that as respondents ${ }^{3}$ relationship intentions increase, so do their expectations that their cell phone network providers should take service recovery action after a billing error. Furthermore, statistical significant relationships were found where, as respondents' relationship intentions increase, so do their expectations of an explanation, apology (both in person and in writing), acknowledgement that the problem occurred, showing of understanding, taking of responsibility, and receiving compensation from the cell phone network provider. A further practical significant finding is that as respondents' relationship intentions increase, their expectations that a manager should intervene accordingly increase. These results support both Kumar et al.'s (2003: 670) and Kim et al. 's (2012: 74) suggestions that customers with higher relationship intentions have higher expectations of their service providers, and that established relationships between service providers and customers resulted in higher expectations of service recovery. Cell phone network providers should realise that eustomers receptive to 
relationship marketing strategies, those customers with relationship intentions, hold higher expectations of service recovery strategies. It is thus recommended that cell phone network providers should always offer service recovery strategies to all customers, but especially so to those customers displaying higher relationship intentions, identified as those customers who reciprocate relationship building efforts and are involved with their service providers by voluntarily providing feedback on their expectations and perceptions of service delivery (Kumar et al., 2003: 670), following a service failure in an effort to restore satisfaction and retain their customers.

Respondents perceived service recovery where the billing error was only rectified so that it would not occur again in future as insufficient service recovery by their cell phone network providers. Results indicated a statistically significant relationship between relationship intention and service recovery after a billing error where the problem is only rectified so that it would not re-occur in future. Moreover, respondents held more favourable perceptions of their cell phone network providers' service recovery efforts after a billing error which included an acknowledgement, apology, explanation, and rectification of the problem. Furthermore, as respondents' relationship intentions increased, so did their favourable perceptions of service recovery after a billing error by their cell phone network providers which included an acknowledgement, apology, explanation, and rectification of the problem. Findings support previous studies advocating that customers with higher relationship intentions are emotionally bonded to their service providers (Kumar et al., 2003: 670), and that an explanation, which shows that the service provider cares for its customers, might help to gain forgiveness from emotionally bonded customers (Mattila, 2004: 144). For this reason, it is recommended that cell phone network providers don't necessarily have to offer customers compensation after a billing error to achieve eustomer satisfaction, as service recovery where an acknowledgement of the mistake, an apology, explanation and rectification of the problem may be sufficiently and favourably received.

It was also found that respondents with high and moderate relationship intentions perceived service recovery strategies of their cell phone network providers including an acknowledgement, apology, explanation and rectification of the problem more favourably, compared to a service recovery strategy only rectifying the problem, than respondents with low relationship intentions, It can therefore be recommended, in line with research pertaining to the influence of relationships on service recovery (DeWitt \& Brady, 2003: 202-203; Forrester \& Maute, 2001: 10; Singh \& Sirdeshmukh, 2000: 163), that cell phone network providers consider customers' relationship intentions as a key determinant of the service recovery required to restore customers' post-recovery attitudes and behavioural intentions. Cell phone network providers should ensure to combine an acknowledgement, apology, explanation and rectification of a billing error made with regard to those customers who have relationship intentions and thus act constructive when service failures occur.

\section{Limitations and directions for future research}

Convenience sampling and the use of only one service failure scenario and two service recovery scenarios limits the researcher's ability to generalise the findings of this study, as different scenarios or real service failures and service recovery strategies could possibly yield different reactions from cell phone users. Also, as not all respondents have contracts with their cell phone network providers, they could possibly find it difficult to imagine themselves experiencing the service failure depicted in the scenario. Future research could replicate the study in different provinces or by considering different services. The influence of relationship intention on customer satisfaction, loyalty and retention following service failure and service recovery should also be further explored. Finally, the influence of relationship intention on the severity of service failures could also be investigated as it is believed that the severity of service failures influences required service recovery (Seawright et al., 2008: 266; Yi \& Lee, 2005: 6).

\section{Conclusion}

The findings from this study support the argument that cell phone users' relationship intentions influence their expectations and perceptions of cell phone network providers' service recovery strategies. For this reason, this study contributes to building theory relating to the influence of relationship intention on expectations and perceptions of service recovery. Findings from the study furthermore provide practical guidelines for cell phone network providers when developing appropriate service recovery strategies to improve customer service and enhance relationships with customers with higher relationship intentions in the event of a service failure.

\section{References}

Andreassen, T.W. 2000. 'Antecedents to satisfaction with service recovery', European Journal of Marketing, 34(1/2): 156-175.

Aquino, K., Tripp, T.M. \& Bies, R.J. 2006. 'Getting even of moving on? Power, procedural justice, and types of offense as predictors of revenge, forgiveness, reconciliation, and avoidance in organizations", Joumal of Applied Psychology, 91(3): 653-668.

Bateson, J.E.G. \& Hoffman, K.D. 2011. Services marketing. 4th Edition. International Edition. Canada: South-Western Cengage Learning.

Beetles, A.C. \& Harris, L.C. 2010. 'The role of intimacy in service relationships: an exploration', Journal of Services Marketing, 24(5): 347-358.

Bell, C.R. \& Ridge, K. 1992. 'Service recovery for trainers', Training and Development: 58-63. 
Berry, L.L. 2002. 'Relationship marketing of services Perspectives from 1983 and $2000^{\circ}$, Journal of Relationship Marketing, 1(1): 59-77.

Bhandari, M.S., Tsarenko, Y. \& Polonsky, M.J. 2007. 'A proposed multi-dimensional approach to evaluating service recovery", Joumal of Services Marketing, 21(3): 174-185.

Blodgett, J.G., Hill, D.J. \& Tax, S.S. 1997. 'The effects of distributive, procedural, and interactional justice on postcomplaint behavior', Journal of Retailing, 73(2): 185210.

Bunker, M.P. \& Ball, D. 2008. 'Causes and consequences of grudge-holding in service relationships', Journal of Services Marketing, 22(1): 37-47.

Bradley, N. 2007. Marketing research: Tools and techniques. New York, N.J.; Oxford University Press.

Cant, M.C. \& Erdis, C. 2012. 'Incorporating customer service expectations in the restaurant industry: the guide to survival', The Journal of Applied Business Research, 28(5): 931-942.

Casado, A.B., Nicolau, J.L. \& Mas, F.J. 2011. 'The harmful consequences of failed recoveries in the banking industry", International Journal of Bank Marketing, 29(1): 32-49.

Cohen, J. 1988. Statistical power analysis for the behavioral sciences. 2nd Edition. Hillsdale, N.J.: Lawrence Erlbaum Associates.

Coulter, R.A. \& Ligas, M. 2004. 'A typology of customerservice relationships: the role of relational factors in classifying customers', Journal of Services Marketing, 18(6): 482-493.

Curran, P.J., West, S.G. \& Finch, J.F. 1996. 'The robustness of test statistics to nonnormality and specification error in confirmatory factor analysis ${ }^{*}$, Psychological methods, 1(1): 16-29.

Dalziel, N., Harris, F. \& Laing, A. 2011. 'A multidimensional typology of customer relationships: from faltering to affective', International Journal of Bank Marketing, 29(5): 398-432.

DeWitt, T. \& Brady, M.K. 2003. 'Rethinking service recovery strategies: the effect of rapport on consumer responses to service failures', Journal of Service Research, 6(2): $193-207$

Dorai, S. \& Varshney, S. 2012. 'A multistage behavioural and temporal analysis of CPV in RM', Journal of Business and Industrial Marketing, 27(5): 403-411.

Dunning, J., Pecotich, A. \& O'Cass, A. 2004. 'What happens when things go wrong? Retail sales explanations and their effects', Psychology and Marketing, 21(7): 553572.
Forrester, W.R. \& Maute, M.F. 2001. 'The impact of relationship satisfaction on attributions, emotions, and behaviour following service failure', The Journal of Applied Business Research, 17(1): 1-14.

Grönroos, C. 2004. 'The relationship marketing process: communication, interaction, dialogue, value', Joumal of Business and Industrial Marketing, 19(2):99-113.

Harrison-Walker, L.J. 2012. 'The role of cause and effect in service failure', Journal of Services Marketing, 26(2): 115123.

Hedrick, N., Beverland, M. \& Minahan, S. 2007. "An exploration of relational customers' response to service failure', Journal of Services Marketing, 21(1): 64-72.

Hess, J., Story, J. \& Danes, J. 2011. 'A three-stage model of consumer relationship investment', Journal of Product and Brand Management, 20(1): 14-26.

Hess, R.L., Ganesan, G. \& Klein, N.M. 2003. 'Service failure and recovery: the impact of relationship factors on customer satisfaction', Journal of The Academy of Marketing Science, 31(2): 127-145.

Holloway, B.B., Wang, S. \& Beatty, S.E. 2009. 'Betrayal? Relationship quality implications in service recovery', Journal of Services Marketing, 23(6): 385-396.

Huang, M.H. 2011. 'Re-examining the effect of service recovery: the moderating role of brand equity', Journal of Service Marketing, 25(7): 509-516.

Huang, J.H. \& Chang, C.C. 2008. 'The role of personality traits in online consumer complaint behaviour and service recovery expectation; ${ }^{*}$ Social Behaviour and Personality, 36(9): 1223-1232.

Independent Communications Authority of South Africa (ICASA). 2012a. Annual report 2011/12. [online] URL: http://www.icasa.org.za/Portals/0/Regulations/Annual\%20R eports/AnnualReport2011-2012.pdf.

Independent Communications Authority of South Africa (ICASA). 2012b. Strategic plan for the fiscal years $2013-$ 2017. [online] URL: http://Www. icasa.org.za/Portals/0/Regulations/Annual\%20R eports/StrategicPlan13-17/SPlan1317,pdf.

Jena, S., Guin, K.K. \& Dash, S.B. 2011. 'Effect of relationship building and constraint-based factors on business buyers" relationship continuity intention', Journal of Indian Business Research, 3(1): 22-42.

Karremans, J.C. \& Aarts, H. 2007. 'The role of automaticity in determining the inclination to forgive close others', Joumal of Experimental Social Psychology, 43; 902-917. 
Kim, W., Ok, C. \& Canter, D.D. 2012. 'Moderating role of a priori customer-firm relationship in service recovery situations', The Service Industries Journal, 32(1): 59-82.

Kim, N. \& Ulgado, F.M. 2012. 'The effect of on-the-spot versus delayed compensation: the moderating role of failure severity', Journal of Services Marketing, 26(3): 158-167.

Komunda, M. \& Osarenkhoe, A. 2012. 'Remedy or cure for service failure? Effects of service recovery on customer satisfaction and loyalty', Business Process Management Journal, 18(1): 82-103.

Kruger, L. \& Mostert, P.G. 2012. 'Young adults" relationship intentions towards their cell phone network operators', South African Journal of Business Management, 43(2): $41-49$.

Kruger, L. \& Mostert, P.G. 2013. 'The influence of relationship intention on relationship length and contractual agreements', Journal of Contemporary Management, 10: 339-361.

Kumar, V., Bohling, T.R. \& Ladda, R.N. 2003. "Antecedents and consequences of relationship intention: implications for transaction and relationship marketing', Industrial Marketing Management, 32(8): 667-676.

Lin, H.H., Wang, Y.S. \& Chang, L.K. 2011. 'Consumer responses to online retailer's service recovery after a service failure', Managing Service Quality, 21(5): 511-534.

Long-Tolbert, S.J. \& Gammoh, B.S. 2012. 'In good and bad times: the interpersonal nature of brand love in service relationships', Journal of Service Marketing, 26(6): 391402.

Lovelock, C. \& Wirtz, I. 2011. Services marketing. People, technology, strategy. 7th Edition. Global Edition. Upper Saddle River, N.J.: Pearson.

Ma, J. 2012. "Does the constumer-firm relationship affect consumer recovery expectations?', Academy of Marketing Studies Journal, 16(2): 17-29.

Mattila, A.S. 2004. 'The impact of service failures on customer loyalty. The moderating role of affective commitment', International Journal of Service Industry Management, 15(2): 134-149.

McCollough, M.A., Berry, L.L. \& Yaday, M.S. 2000. 'An empirical investigation of customer satisfaction after service failure and recovery', Journal of Service Research, 3(2): 121-137.

McCullough, M.E., Worthington, E.L. \& Rachal, K.C. 1997. 'Interpersonal forgiving in close relationships', Journal of Personality and Social Psychology, 73(2): 321-336.
Michel, S. 2004. 'Consequences of perceived acceptability of a bank's service failures', Journal of Financial Services Marketing, 8(4): 367-377.

Morrisson, O. \& Huppertz, J.W. 2010. 'External equity, loyalty program membership and service recovery', Journal of Services Marketing, 24(3): 244-254.

Nikbin, D., Ismail, I., Marimuthu, M. \& Abu-Jarad, I.Y. 2011. 'The impact of firm reputation on customers' responses to service failure: the role of failure attributions', Business Strategy Series, 12(1): 19-29.

Pallant, J. 2010. SPSS Survival manual. 4th Edition. New York, N.Y.: McGraw-Hill.

Palmatier, R.W., Scheer, L.K., Evans, K.R. \& Arnold, T.J. 2008. 'Achieving relationship marketing effectiveness in business-to-business exchanges', Journal of The Academy of Marketing Sciences, 36: 174-190.

Petruzzellis, L. 2010. 'Mobile phone choice: technology versus marketing. The brand effect in the Italian market', European Journal of Marketing, 44(5): 610-634.

Prasongsukarn, K. \& Patterson, P.G. 2012. 'An extended service recovery model: the moderating impact of temporal sequence of events", Journal of Services Marketing, 26(7): $510-520$.

Price, L.L. \& Arnould, E.J. 1999. 'Commercial friendships: service provider-client relationships in context', Journal of Marketing, 63(4): 38-56.

Robinson, L., Neeley, S.E \& Williamson, K. 2011. 'Implementing service recovery through customer relationship management: identifying the antecedents', Journal of Service Marketing, 25(2): 90-100.

South African Audience Research Foundation (SAARF). 2012. Cell phone trends. [online] URL: http://www.saarf.co.za/amps/cellphone.asp.

Seawright, K.K., DeTienne, K.B., Bernhisel, M.P. \& Larson, C.L.H. 2008. 'An empirical examination of service recovery design', Marketing Intelligence \& Planning, 26(3): 253-274.

Seo, D., Ranganathan, C. \& Brady, Y. 2008. 'Two-level model of customer retention in the US mobile telecommunications service market', Telecommunications Policy, 32: 182-196.

Singh, J. \& Sirdeshmukh, D. 2000. Agency and trust mechanisms in consumer satisfaction and loyalty judgments', Joumal of The Academy of Marketing Science, 28(1): 150-167. 
Smith, A.K., Bolton, R.N. \& Wagner, J. 1999. 'A model of consumer satisfaction with service encounters involving failure and recovery', Journal of Marketing Research, 36(3): 356-372.

Stevens, J.P. 2009. Applied multivariate statistics for the social sciences. 5th Edition. New York, N.Y.: Routledge.

Takaku, S. 2001. 'The effects of apology and perspective taking on interpersonal forgiveness: a dissanance-attribution model of interpersonal forgiveness', The Journal of Social Psychology, 141(4): 494-508.

Tax, S.S. \& Brown, S.W. 1998. Recovering and learning from service failure', Sloan Management Review, 49(1): 7588. Fall.

Tax, S.S., Brown, S.W. \& Chandrashekaran, M. 1998. 'Customer evaluations of service complaint experiences: implications for relationship marketing', Joumal of Marketing, 62: 60-76.

Tsarenko, Y. \& Tojib, D.R. 2011. 'A transactional model of forgiveness in the service failure context: a customer-driven approach', Joumal of Services Marketing, 25(5): 381-392.

Van Niekerk, L. 2012. South Africa yearbook 2011/12 Communications. [online] URL: http://Www.gcis.gov.za/sites/www.gcis.gov.za/files/docs/res ourcecentre/yearbook2011/10_Communications.pdf.

Varki, S. \& Wong, S. 2003. 'Consumer involvement in relationship marketing of services', Journal of Service Research, 6(1): 83-91.

Wang, C. \& Mattila, A.S. 2011. 'A cross-cultural comparison of perceived informational faimess with service failure explanations', Journal of Services Marketing, 75(6): 429-439.

Yi, Y. \& Lee, I. 2005. 'An empirical study on the customer responses to service recovery in the context of service failure', Seoul Journal of Business, 11(1): 1-17.

Yuksel, A., Kilinc, U.K. \& Yuksel, F. 2006. 'Cross-national analysis of hotel customers" attitudes toward complaining and their complaining behaviours', Tourism Management, 27. 11-24.

Zeithaml, V.A., Berry, L.L. \& Parasuraman, A. 1993. 'The nature and determinants of customer expectations of service, Journal of The Academy of Marketing Science, 21(1): 1-12. 